\title{
Developing Supplementary English Material based on Project Based Learning for Nursing Students of Medical Department of SMK Citra Semesta Indonesia Yogyakarta
}

\author{
Hikmah Pravitasari ${ }^{1}$ \\ ${ }^{1}$ Muhammadiyah Surakarta University, Jl. Ahmad Yani, Pabelan, Kartasura, Surakarta, \\ Central Java, Indonesia
}

\begin{abstract}
The objectives of this research were: (1) to investigate the quality of the existing course book used in SMK CSI Yogyakarta, and (2) the development of the Supplementary Project book in SMK CSI Yogyakarta. This research was conducted at SMK Citra Semesta Indonesia (CSI) Yogyakarta in 2016. This research was categorized into Research and Development (R \& D). It was conducted in two steps, they were exploration and development. The exploration step were literature review, field study, need analysis, and product planning. While the development step were prototype development, field testing, and final product. In analysing data, Miles and Huberman's model was considered to be used through data reduction, data display, and conclusion. After conducting need analysis through interview, questionnaire, observation, and document analysis, the researcher concluded that there was a need of supplementary English material to fulfil the students' need toward the material at vocational high school in nursing program. The existing course book did not match well with the students' need of nursing field. In development stage, the researcher designed a prototype of supplementary English material referring to Project-based Learning (PBL) method and English for Specific Purposes (ESP). Then, it was validated and reviewed by five experts. To get the feasible product, the prototype was implemented three times in the classroom. The final try out, class observation, questionnaire, and Focus Group Discussion (FGD) approved the draft's feasibility and appropriateness as supplementary material to teach students of nursing skill program in vocational high school.
\end{abstract}

Keywords: ESP; R\&D; PBL; supplementary book; vocational school

\section{INTRODUCTION}

Recently, there are many English course books for the students of vocational high schools. Some books that are often used by English teacher are Global Access, English for Vocational High School, Interchange, and Get Along. Each of them promotes different approach and also interesting topic and display. Although there are many course books published with different kinds of approach offered, language practitioners should choose the best and standard books based on the students' need. According to Cunningsworth [1] there are several guidelines for standardize course books used in the classroom. First, course books should correspond to learners' needs. Second, course 
books should reflect the uses (present or future) which learners will make of the language.

Hutchinson and Waters [2] defined that ESP is an approach to language learning which is based on learner's need which means that all contents and methods are based on the needs of the students. Strevens in Richards [3] argued that the content of ESP course is determined by the basic skills due to the learners' purpose; the grammatical selection including the vocabulary and grammatical pattern and the language functions; topics and themes related to the learners' purpose, and the needs of communication.

By doing the observation and informal talk with the English teacher, it was found that in this school only used one book which designed by LP2IP Yogyakarta for all skill programs. The book is "English for Vocational Schools" which has three levels; novice, elementary, and intermediate. The novice level was designed for first grade, elementary level for second grade, and intermediate level for third grade. This book has a series, book A and B for every level. Each series designed for one semester. But the teacher only used one series (book A) in all classes, included nursing class, because every book has many materials which should be learn, but the students cannot reach them all in two semesters. Based on analysis on this book, it is found that the input text and language context has not matched with the nursing skill program, the content used English in general topics and the language are very high for the students' level of English in grade $\mathrm{X}$ of English for nursing class in SMK Citra Semesta Indonesia Yogyakarta. The teacher finds some difficulties in using the book, so they make focus learning material and drilling vocabulary in the first meeting. It becomes the reason why the students of nursing skill program, especially in English for nursing class need additional specific English learning material in more simple content which can guide the students to improve their English.

Based on deep interview with English teacher of nursing skill at SMK Citra Semesta Indonesia Yogyakarta, vocational high school students need a good competence in English, because this competence is much needed for them in the work field. The students of grade X in ESP class have high motivation in learning English, and they need specific learning material in English based on their needs and need more emphasizing in integrated English skills especially speaking skill. Speaking skill must become the priority in nursing program, because in the work field, they will take care the patients and help them to explain the doctor's prescriptions. ESP class has an English syllabus from English teacher community or Indonesian teachers usually called Musyawarah Guru Mata Pelajaran (MGMP) and LP2IP Yogyakarta.

The teacher should choose an appropriate method in order to make the students achieve adequate competence in learning English in the classroom. One of them is Project-based Learning (PBL). Project-based Learning is an instructional approach that contextualizes learning by presenting learners with problems to solve or products to develop. Project-based Learning functions as a bridge between using English in class and using English in real life situations outside class [4]. According to Cunningsworth [1] where material is lacking in a particular area or deals with the area in an unsuitable way, the options are to find supplementary material from other published sources or to produce your own material. Based on the description above, it is necessary for the researcher to propose possible solution which may bridge the gap between the general English curriculum offered in vocational high school and the needs of students for their future careers. Therefore, the researcher is going to develop a supplementary English 
material based on Project-based Learning for nursing students of medical department of SMK Citra Semesta Indonesia Yogyakarta to compile a set of materials that is relevant to students' needs.

The researcher observes some previous studies before conducting the research in order to know how far the PBL method and R\&D research are used in language teaching. There are several researchers who have conducted the research used PBL approach and R\&D. Those are carried out by Roza [5] "Project Based Learning in the Algerian Secondary School (An Investigation and Evaluation of Syllabuses and Textbooks)". This research, aims to evaluate the extent to which the secondary school syllabuses and textbooks of English favor the integration of project pedagogy into ELT, Novitasari [6] "Developing ESP Textbook for Culinary Skills Program of Vocational High School Using Task-based Language Teaching". The aim of this research is developing English for Specific Purposes (ESP) textbook to fulfill the students' need toward the material at vocational high school using Task-based Language Teaching (TBLT). It was conducted to investigate the quality of the existing course book used in vocational high school and the development of the ESP textbook using TBLT at SMKN 3 Pacitan, and Syaifudin [7] "Developing Supplementary Reading Materials for Seventh Grade Students of SMP Negeri in Surakarta based on Curriculum 2013". The aims of this research are to investigate the quality of "When English Rings A Bells" as the existing course book to teach reading for the seventh grade of Junior High School in Surakarta and to describe the development of supplementary reading materials for the seventh grade of Junior High School in Surakarta based on curriculum 2013.

In this current research, the researcher tries to investigate the quality of "English for Vocational Schools" as the existing course book and to develop a supplementary English material for tenth grade students of vocational school in nursing program. The supplementary English material guides the students to make some individual or group projects using PBL method in real situation based on the topic given. The supplementary English material will be developed based on the concept in integrated skills, English for Specific Purpose procedures, PBL, and supplementary material. It can accompany the other learning materials for students to have independent learning and make a compilation between students and the teacher.

\section{METHOD}

This research used the research and development methodology or it is known as R\&D study. Gall and Borg [8] stated that R\&D is an industry-based development model in which they are systematically field tested, evaluated, and refined until they met specified criteria of effectiveness, quality, or similar standards. In line with this, Sugiyono [9] states that research and development ( R \& D) is a research method used to produce a product and examine the effectiveness of the product. It is aimed to help teachers and students to get the best educational product.

Based on the aim of this study, this study is classified as a Research and Development (R \& D). The aim of this research is to develop an instructional project book which guides the students to make some individual or group projects using Project-based Learning approach in medical school. In this research, the product is developed by considering to the strengths and weaknesses of existing learning material or textbooks and some related theories in order to produce an appropriate material based 
on vocational school context. In developing it, the use of Project-based Learning and English for Specific Purposes will be explored much more. There are two stages in this research, namely exploration and development. Each stage has different steps and purposes.

The steps of R\&D can be classified into four big stages which are included some operational steps. The four stages are (1) exploration, (2) product development, (3) field testing, and (4) dissemination and implementation. However, only exploration and development stage were done in this research. Because of the time, field testing and dissemination were not conducted.

Such simplification is termed by Borg and Gall [8]. They state that for thesis and dissertation, it is best to undertake a small-scale project and to limit development to just few steps of the R \& D cycle. It means that the implementation can be adjusted based on the condition. Because all of steps need more time in conducting the research, this research also used modified procedures of $\mathrm{R} \& \mathrm{D}$. Therefore, this research will be conducted in two stages namely; exploration stage, and development stage. The explanation of each stage will be discussed as follows.

\section{Exploration Stage}

The purpose of exploration stage is to set up a base of theory, to analyse the existing English course books and to conduct need analysis related to the draft model proposed by the researcher. The information should be collected deeply, accurately and broadly. It should be known the quality of the product and its effect. The exploration in this research was done by reviewing literature related to the topic and doing field study. The strategy used in this stage is qualitative study. The existing problems were described and the researcher interpreted it into general conclusion.

This research was conducted in SMK Citra Semesta Indonesia Yogyakarta which is located at Jl. Durungan Wates Kulon Progo Yogyakarta. It is one of the vocational high schools in Yogyakarta that focuses on studying pharmacy and nursing. The subjects of this research were the tenth grade students of nursing skill program of SMK Citra Semesta Indonesia Yogyakarta in the first semester of academic year of 2015/2016. The subjects were chosen by using non-equivalent control group design technique. A nursing skill program was chosen because of its relevance and need for mastering English higher than the other programs. The students of nursing skill program will interact with many people not only with domestic patients but also international patients and of course they related to the medical industry. The resources of this research were: (1) the English teacher of nursing skill program grade X in SMK Citra Semesta Indonesia Yogyakarta, (2) tenth grade students of nursing skill program, and (3) documents.

The data of this research were qualitative. In conducting a research, the instruments were needed to collect the data. The technique of triangulation is used to make the result valid through collecting the same kind of data from different resources. According to Wiersma in Sugiyono [9], triangulation is qualitative cross validation. In this research, the researcher also used more than one instrument namely interview, questionnaire, observation and document analysis. To analyse the data, the researcher used the qualitative descriptive analysis, because the qualitative research was used in this step. The qualitative analysis used in this research was an interactive analysis model developed by Miles and Huberman in Sugiyono [9] who provide some steps in 
analysing the qualitative data. The steps are: (1) data reduction, (2) data display, and (3) drawing conclusion and verification. The output of this stage was the result of course book analysis and need analysis toward the product developed by the researcher. The output was used to develop the prototype in the next stage.

\section{Development Stage}

The purpose of the development stage in this research was to get feasibility of model draft developed in previous stage. The feasibility could be gained from practical side, time, students' response, and the impact to the teaching and learning process. Draft model was prototype that should be tried out and tested in the field empirically to get constant model. After being tried out in the class, the prototype of the product was evaluated and revised by the researcher in order to result a qualified final product. The beginning of the development stage, the researcher developed ESP syllabus and constructed lesson plan to the tenth grade of vocational high school in SMK Citra Semesta Indonesia Yogyakarta. The next step was prototype development. In this phase, the researcher asked some experts to give validation of the prototype design. After that, the researcher conducted the try out. The purposes of the try out were to know the product practically, effectiveness, and the result of teaching using the product. The stage of implementation contains the evaluation process also. In this step, the evaluation was conducted to measure up the response given by the teacher and the students. After trying out, closed questionnaire was distributed to the teacher and the students in order to find out the response after being used and taught using the product. The next step of try out was always based on the previous results. The cycle consisted of research findings pertinent to the product to be developed, developing the product based on the findings, field testing it in the setting where it was used eventually, and revising it to correct the deficiencies found in the field testing. In this stage, the researcher used triangulation which was carried out by having discussion with the teacher and the students.

Data collecting techniques used in this research were: (1) questionnaire, (2) observation, and (3) Focus Group Discussion (FGD). The qualitative data were collected from observation data stored in the field notes. The qualitative analysis used in this research was an interactive analysis model developed by Miles and Huberman. The quantitative data also used in this stage. This analysed data were from the questionnaire distributed to the teacher and the students based on Likert scale in five levels. There was range provided between 5 meaning very good to 1 meaning very poor. To analyse the data, the researcher used percentage descriptive technique. The output of this stage was the final product namely a Supplementary Project Book using Project-based Learning for nursing skill program of vocational high school.

\section{FINDINGS AND DISCUSSION}

There are two stages which are discussed in the findings as follows: exploration, and development stage. The exploration stage consists of four parts of findings: (1) the analysis of the existing condition in this case is the description of the existing and quality of course book, (2) the analysis of syllabus used in nursing skill program, (3) the result of need analysis obtained from questionnaire, interview, observation, and 
document analysis, and (4) product planning. The development stage consists of four parts: (1) prototype development, (2) expert validation, (3) prototype try out, and (4) the final draft of "Nursing Assistant Project". The explanation of each stage will be discussed as follows.

\section{Exploration Stage}

The analysis of course book is based on the Cunningsworth (1995) model that based on: (1) impressionistic overview evaluation and (2) in-depth analysis evaluation. Based on interview and observation, it was found that the teachers and the students of nursing class use the type of the English module which is entitled "English for Vocational Schools IA". After conducting document analysis for the existing course book, it was found that the book is written by Dra. Hj. Yiyis Krisnani, M. Hum., and the publisher is Drs. Maskurun. The book size is 16 x $21 \mathrm{~cm}$. This book was published in 2011 by LP2IP (Lembaga Pemacu Prestasi Bidang Ilmu Pengetahuan), Yogyakarta [10]. LP2IP is one of the educational publisher books in Yogyakarta. The materials inside are arranged in eleven chapters which consists of 140 pages. It is published only when an institution school or someone ordered.

English for Vocational Schools IA is arranged based on KTSP 2006 and SKL (Standar Kompetensi Lulusan) in novice level. It focuses on the four language skills namely listening, speaking, reading, and writing. This book is arranged based on tasks which consist of 17 to 20 tasks in each chapter. This book also provides student and teacher guideline to use this book. This book can help the students to master and develop their potencies based on their abilities and study program in general. To support the mastery of the students' abilities, this book is also equipped with Competency Standard, Basic Competence, Learning Material, and Performance Criteria in every chapter in the first page of the chapter.

In-depth analysis evaluation is more penetrating in its approach and has its own agenda. The analysis of textbook was based on the Cunningsworth (1995) model. There are eight indicators proposed by him as the criteria for book evaluation. They are (1) objective and approach, (2) design and organization, (3) language content, (4) language skill, (5) topic, (6) methodology, (7) teacher's book, and (8) practical consideration.

Based on the result of analysis, the researcher drew a summary and conclusion. The researcher found some strengths and weaknesses of the existing course book used in X grade students of nursing skill program in SMK Citra Semesta Indonesia Yogyakarta. The strengths were: (1) "English for Vocational Schools IA" allowed different teaching and learning style, (2) The design, organization, and topic of "English for Vocational Schools IA" developed based on SK and KD in KTSP 2006, and (3) "English for Vocational Schools IA" provided some kind of dialogues based on expression for practice English.

There were also some points that the researcher considered as weaknesses found inside. They were: (1) The book is quite general for vocational class especially for nursing skill program that why it does not match with the need of learner and teaching situation, (2)The design and organization of the content is based tasks, however the grading of the tasks are not clear and there are some unclear illustration pictures which are not authentic and contextual, (3) The book does not include material for pronunciation work and vocabulary list, (4) Some of the materials are very complicated to use by the students, so they still need teacher's help for using the book, (5) The topics 
are too general. It cannot expand the students' awareness and enrich their experience, and (6) The package of the book is not attractive and not lost-lasting.

Based on the summary above, the researcher concluded that "English for Vocational Schools IA" was not appropriate for guiding teaching and learning English in nursing class, and a supplementary project book was needed to guide teaching and learning in nursing class.

There are some points that are found in the preliminary research. They are as follows: (1) English for Vocational Schools IA was used in teaching and learning at the nursing class. The book was selected because of the reference from local government to all SMK in Kulon Progo Yogyakarta. The book analysis was conducted by referring to Cunningworth model. It was found that generally the book content is too general to be used for the nursing students. The book was developed based on KTSP 2006. However, it does not match well with the students' need toward nursing skill program. In addition, there is no pronunciation and vocabulary list to guide the students understand the difficult words written in the book. Therefore, the researcher developed a supplementary project book using Project-based Learning in vocational school context for the tenth grade students of nursing skill program at SMK Citra Semesta Indonesia Yogyakarta, and (2) the students and the teachers approved that there were a need of supplementary project book to guide their teaching learning process in the classroom beside it could also help students to have independent learning and doing some English projects which match with their program and produce a product as the result of their learning process. The responses and information given by the teachers and students showed that the existing learning sources were not really appropriate to use for nursing class in classroom, so that a supplementary project book was $100 \%$ needed.

\section{Development Stage}

After obtaining the data about the learners' needs, the next step was planning the product. The researcher planned the product based on the need analysis that related to target situation analysis and learners' need analysis. The data obtained from the need analysis and it was used as a guideline to design the product. Before developing the prototype, the researcher describes the planning of the product.

The researcher plans the supplementary project book firstly by proposing the title of the book, the model of learning strategy referring to Project-based Learning approach. The book title is "Nursing Assistant Project". The researcher uses the name under the consideration that the book is to help students to learn English based on the project given in the book. The researcher means to support them not only to talk actively and easily in English but also to do some projects as an authentic learning and produce a product as the result of their learning process. It can help the students of nursing program are demanded to communicate using English, because in the work field, they have to take care local and international patients.

The developing this prototype mainly focuses on the students on novice level in tenth graders of vocational high school. The product is written based on SK and KD of vocational high school in the first semester. It based on the existing course book which designed in one semester. Moreover, the researcher tries to complete the basic competence in first semester because the existing course book only provides four basic competences. From each basic competence, the researchers will develop some indicators for four language skills and also the character buildings that will be inserted. 
It was written in a course grid. The course grid contains the subject matter, skills, indicator, character building, input texts, language functions, vocabularies, and grammar. Finally, the researcher designed the task for four skills that are suitable with the students' need and compatible with the existing curriculum. Each chapter of the "Nursing Assistant Project" was developed based on each standard of competence. The draft material consists of 5 chapters and each chapter has a number of projects and activities. Each unit contains some activities or situation that may happen in the students' working place. The projects were designed based on the level of difficulties. Hence, there is project grading from easy to difficult level. In the beginning of the chapters, it presents some objectives that need to be achieved in learning each chapter. The following is the topic of each unit; developed from each standard of competence. Chapter 1 is "Patient Admissions, chapter 2 is "Nursing Tools", chapter 3 is "Personal Care", chapter 4 is "Signs and Symptoms", and chapter 5 is "Food and Nutrition". There is a final project in every chapter. Each chapter consists of some activities to set up the students in conducting the final project. The activities were arranged based on Wrigley's Project-based Learning method. There are four main steps in the process of project-based work based on Wrigley in Donna and Carol [4] as follows: Topic Selection, Making Plan, Doing Research, and Sharing Result. The total page of the supplementary project book is 150 pages.

The researcher herself designed the cover and layout as well. The cover consists of the title of the book. This is the colourful cover which was designed to be eye-catching and appealing. The following is the cover of "Nursing Assistant Project". The structure planning of prototype model is in the form of: (1) title, (2) cover, (3) preface, (4) process of project-based work, (5) phonemic chart, (6) table of contents, (7) material, (8) listening script, and (9) bibliography. After planning the product, the researcher developed the prototype.

The next stage is the validation given by expert toward the prototype design before being tried out in the real classroom application. Expert validation was conducted to get some advice and suggestion for the draft improvement. The evaluation from the expert is very crucial as an input to revise the draft. There are four kinds of expert who reviewed the Nursing Project draft. The first expert is the expert of English language teaching (ELT) in UMS, the second expert is the expert of Nursing in UMS, the third expert is the expert of Language, and the forth expert is the practitioner of textbook layout from the design team of SMK Citra Semesta Indonesia Yogyakarta. The experts are very helpful in evaluating the quality of the developing guideline. Based on some suggestions, the researcher revised and then developed the prototype. The expert of ELT gave more comments and suggestion in the content of the draft. The total score gained from the two experts of ELT are 201 and 166 from 255. The percentage means score is $71.96 \%$ which categorize into good material. The expert of Language gave comments and critics in the language content and language skills of the draft. The result shows that total score is 93 (74.4\%) from 125. It is categorized into good material from language aspect. The expert of Nursing gave some comments and suggestion in the design, organization, skill, topic, and content of nursing aspect. The total score gained from the expert of Nursing is $130(81.25 \%)$ from 160. It is categorized into excellent. The expert of Layout gave more comments and suggestion in cover, font, and harmonization of the draft. The result shows that total score is $88(88 \%)$ from 100. It is categorized into excellent. According to the experts, there are some aspects that should be changed in the cover of the draft. The experts also suggested revising the language 
instructions, vocabulary organization, change listening audio, and revise the website citations. Moreover, the experts asked to add phonetic transcription and rubric assessment.

The recommendations from the experts were very beneficial for the researcher to do revision and to develop the more complete one. Having received feedbacks from the experts, the researcher conducted revisions. The revision was held to accommodate the concept of Project-based Learning materials suggested by the experts. The revision was also meant to make the activities in with the English for Specific Purposes (ESP) for nursing program.

As soon as the prototype design validated by the expert, the researcher continued the development process of the product into the next cycle. The researcher arranged a series of field testing to see the strength and the weaknesses of the product when it dialled with the real subject of the study. This cycle was also aimed to collect the data from the teacher and the students about how the product works in the teacher's perspective and class implementation.

Trying out was implemented by implementing the draft of "Nursing Assistant Project" in the class. The purpose of the try out is to get the feasibility of the product. The result of the try out was the data about the feasibility of "Nursing Assistant Project" in teaching English for tenth grade students of nursing program. There are three techniques employed in collecting the data, observation, FGD, and questionnaire. The try out is obtained through try out followed by Focus Group Discussion (FGD). FGD with the teacher and the students was conducted to evaluate the implementation and the improvement of the guideline for the second till the third try out. The ultimate goal of the activity is to obtain the feasibility of the product. The data about the teaching and learning process were collected by using passive participant observation. During the implementation, the teacher observed the classroom activities while the researcher taught the students using the book. The teaching and learning process using the draft was observed.

The try out stopped when the product was considered feasible or considered as optimal and consistent as possible. At the end of the try out, the researcher distributed questionnaires to the teacher and the students to know their opinion about the product. After that, evaluation was applied after trying out the draft in the class to get some evaluation and suggestion to revise the product. The try out and revision were conducted in several time to get qualified and feasible product. The researcher tried out three chapters from five chapters. The researcher tried out three times.

The try-out of the prototype was implemented three times. The researcher merely tried out three chapters from five chapters available in "Nursing Assistant Project". Each meeting consisted of $2 \times 45$ minutes. The English subject was taught twice a week every Thursday and Saturday. The first try out was done in October 13th, 15th, and 20th 2016. The second try out was implemented in October 29th, and November 3rd, 5th 2016. While the third try out was carried out in November 10th, 12th, and 17th 2016. The try out was conducted in tenth grade students of nursing skill program of SMK Citra Semesta Indonesia Yogyakarta. The teacher who taught the class is Mr. Sunari, S.Pd. The number of the students was 32 students which consist of thirty girls and two boys. Then, the researcher becomes the observer of classroom teaching and learning process.

Try out of the product that has been conducted in class requires finishing by examining the finding of try out. The result of this stage is the final product of English 
supplementary project book for the tenth grade students of nursing skill program of SMK Citra Semesta Indonesia Yogyakarta. During the try out, the product has been changed and revised. The revisions are based on findings in FGD, result of the questionnaire given to the teacher and the students, and observation class. Therefore, the guideline is developed based on the need of the students and the teacher. Finally, the product of "Nursing Assistant Project" is valid and feasible.

\section{CONCLUSION}

According to the conclusions, the researcher would like to give some implications which are implied in this research. (1) Teacher's role; materials developed by the researcher can support and assist the teacher to teach English and improve his role as facilitator, motivator, and manager in the class. By using Project-based Learning approach that is applied inside the material, the activity in the class becomes more interesting and varied. (2) Students' motivation; "Nursing Assistant Project" was designed based on the students' need and skill program and therefore the topic is something related to their world. (3) The use of learning material; by using "Nursing Assistant Project", the situation and condition of the class will be interesting. The activities are designed in interesting way which varied projects.

Related to the findings, some suggestions are given to (1) The English teacher; the teachers of vocational high school may use this Nursing Assistant Project book as supplementary material to support the use of course book at school. It can provide the students many exercises and projects that close to their real life. Consequently, it can improve the students' achievement in English learning and qualified workers in the future. (2) Educational officers; the educational officers should make a policy to recommend course books that are suitable with the students' skill program. There should be a specific guideline to select appropriate course book for vocational students. (3) The other researchers; this research could be used as a source for the other researchers to make a research in the same field. For the improvement of the teaching materials, it was suggested to other researchers to conduct similar research to find out the most appropriate material based on the students' needs.

\section{REFERENCES}

[1] Cunningsworth, Alan. (1995). Choosing Your Coursebook. Great Britain: The Bath Press. pp. 15 17:138.

[2] Hutchinson, Tom \& Alan Waters. (1987). English for Specific Purposes A Learning-centred Approach. New York: Cambridge University Press., pp. 8-9.

[3] Richards, Jack C. and Rodgers, Theodore S. (2001). Approaches and Methods in Language Teaching. New York: Cambridge University Press., pp. 26.

[4] Donna, Moss \& Carol, V. D. (1998). Project-based Learning for Adult English Language Learners: National Clearinghouse for ESL Literacy Education Washington DC, Adjunct ERIC Clearinghouse for ESL Literacy Education Washington DC., pp. 1:2.

[5] Roza, Aimeur. (2011). Project Based Learning in the Algerian Secondary School (An Investigation and Evaluation of Syllabuses and Textbooks). Unpublished Thesis. Tizi-Ouzou: Mouloud Mammeri University. 
[6] Novitasari. (2014). Developing ESP Textbook for Culinary Skills Program of Vocational High School Using Task-Based Language Teaching. Unpublished Thesis. Education and Teacher Training Faculty: Sebelas Maret University.

[7] Syaifudin, Makmun. (2015). Developing Supplementary Reading Materials for the Seventh Grade Students of SMP Negeri in Surakarta based on Curriculum 2013. Unpulished Thesis. Education and Teacher Training Faculty: Sebelas Maret University.

[8] Gall, Meredith D \& Walter R. Borg. (1983). Educational Research: Fourth Edition. NY: Longman Inc., pp. 569:792.

[9] Sugiyono. (2012). Metode Penelitian Pendidikan: Pendekatan Kuantitatif, Kualitatif, dan R\&D. Bandung: Alfabeta., pp. 408:372:337-345.

[10] Krisnani, Yiyis. (2011). English for Vocational Schools IA. Yogyakarta: LP2IP. 